\title{
Development of enzyme linked immunosorbent assay (ELISA) to detect antibodies to Pseudomonas aeruginosa cell surface antigens in sera of patients with cystic fibrosis
}

\author{
MOIRA M BRETT, ${ }^{*}$ A T M GHONEIM, $\dagger$ J M LITTLEWOOD, $\ddagger$ M S LOSOWSKY* \\ From the *Department of Medicine, $\uparrow$ Microbiology, and $\ddagger$ Paediatrics, St James’s University Hospital, Leeds
}

SUMMARY An enzyme linked immunosorbent assay (ELISA) to measure free serum IgG antibodies to Pseudomonas aeruginosa in patients with cystic fibrosis was developed. Seven strains of $P$ aeruginosa cells, treated with glutaraldehyde and representing the most commonly isolated serotypes in our cystic fibrosis unit, were used. The specificity of the test was confirmed by the absence of cross reacting antibodies to other Gram negative bacteria. The results showed differences in the titres of antibodies at different stages of $P$ aeruginosa infection.

Because of its reproducibility, specificity, and sensitivity these preliminary results suggest that this test may be of value in monitoring the progress of Paeruginosa infection in patients with cystic fibrosis.

Pulmonary infection after colonisation with $P$ aeruginosa is an important cause of morbidity and mortality in patients with cystic fibrosis. ${ }^{1}$ Once $P$ aeruginosa has become established in the lungs it is never completely eradicated, even after aggressive antimicrobial treatment. The early stages of colonisation and infection of the lungs in such patients are important because tissue invasion may be delayed or even prevented by early treatment with antibiotics.

Growth of Paeruginosa from the respiratory tract may represent colonisation (the presence of the organism in the airways without clinically important tissue invasion or systemic immune response), or infection (with tissue invasion and damage accompanied by an immune response). There are no sensitive tests which differentiate between colonisation and infection.

Hoiby et al have shown a correlation between serum antibodies to sonicated $P$ aeruginosa cells and the clinical state of patients, using crossed immunoelectrophoresis. The number of precipitin lines representing different antibodies, however, showed an increase only in patients with chronic Paeruginosa

Accepted for publication 23 April 1986 infection. This test could not identify colonised patients nor patients infected for less than sif months. ${ }^{2}$

The purpose of this study was to develop an enzyme linked immunosorbent assay to measure free serum IgG antibodies to surface antigens of $P$ aeruginosa, which would be suitable for routine use.

\section{Patients and methods}

Sixteen patients with cystic fibrosis attending the paediatric and adult cystic fibrosis clinics at this hospital were investigated. Diagnosis of the disease was confirmed by at least one sweat test. ${ }^{3}$ In five patients with cystic fibrosis (three females, two males) Paeruginosa had never been isolated from sputum. Their age range was 1-15 years, mean (SE) was 8.4 $(2 \cdot 1)$. In seven (four females, three males) $P$ aeruginosa had been isolated from sputum on one or more occasions during the previous year but these patients had no recognisable illness attributable to that organism. Their ages ranged from 6-24 years, mean $15(2.6)$ years. In four patients with cystic fibrosis (three females, one male) Paeruginosa had been isolated continuously from their sputum cultures for at least a year. Their age range was 12-24 years, mean $16 \cdot 25(2 \cdot 3)$ years. They had recognisable chest illness attributable to Paeruginosa. 
CONTROLS

These comprised 17 patients (seven females, 10 males) attending the paediatric clinic at this hospital. The mean age was $9.54(1.42)$ years ranging from 5 months to 15 years. None had any evidence of lung disease or Paeruginosa infection. Conditions were diabetes (3), anaemia (2), short stature (2), lethargy (1), intestinal polyp (1), oesophageal reflux (1), haematemesis (2), malaria (1), congenital emphysema (1), severe retardation (2) and hypothyroidism (1).

SERUM

Serum from patients and controls was stored at $-20^{\circ} \mathrm{C}$ until immediately before use.

STRAINS

Clinical isolates of Paeruginosa

These were identified from sputum samples of patients with cystic fibrosis by the API 20 NE series of biochemical reactions.

\section{Gram negative bacteria other than Paeruginosa}

Clinical isolates of Escherichia coli, Enterobacter cloacae, Citrobacter diversus, Citrobacter amolenitus, Klebsiella pneumoniae, Serratia marcescens, and Proteus mirabilis, which had been obtained from sputum samples of patients with cystic fibrosis, were used to test the antigenic cross reactivity with $P$ aeruginosa. Strains were stored on nutrient agar slopes at $4^{\circ} \mathrm{C}$ and in nutrient broth at $-196^{\circ} \mathrm{C}$.

\section{SEROTYPING}

$P$ aeruginosa was serotyped as soon as possible after isolation and identification. The Paeruginosa antiserum set produced by Difco (Detroit, United States of America) was used. This is based on the International antigenic typing scheme. ${ }^{4}$

\section{ENZYME LINKED IMMUNOSORBENT ASSAY}

(ELISA)

An ELISA was developed to measure IgG antibodies against $P$ aeruginosa antigens. A series of assays was performed with the following antigens: viable cells; glutaraldehyde or heat treated cells; and sonicated cells. Cells treated with glutaraldehyde gave the most reproducible results. Each strain was grown overnight as a lawn on blood agar plates at $37^{\circ} \mathrm{C}$. Growth from each plate was removed in $10 \mathrm{ml}$ phosphate buffered saline $(\mathrm{pH} \mathrm{7.4)}$ and centrifuged at $10000 \times g$ for 10 minutes at $4^{\circ} \mathrm{C}$. The pellet was washed twice and then resuspended in phosphate buffered saline at $4^{\circ} \mathrm{C}$ to a concentration of $10^{10}$ colony forming units $/ \mathrm{ml}$. Methylglyoxal (Sigma) was added to give a final concentration of $0.3 \% \mathrm{v} / \mathrm{v} .{ }^{5}$ The solid support used was microtitre plates (Immulon grade A, Dynatech). Bacterial cell suspension $(120 \mu \mathrm{l})$ was added to each well and incubated overnight at $4^{\circ} \mathrm{C}$. A single serotype was used in each plate. The unbound supernatant was then aspirated and $120 \mu \mathrm{l}$ glutaraldehyde $0.5 \% \mathrm{v} / \mathrm{v}$ was added and incubated at room temperature for 30 minutes. This was aspirated and the wells washed three times for five minutes in phosphate buffered saline. Unbound sites were blocked by overnight incubation at $4{ }^{\circ} \mathrm{C}$ with $120 \mu 11 \%$ bovine serum albumin (BSA) in phosphate buffered saline. After washing three times in phosphate buffered saline and drying the plates were stored at $4{ }^{\circ} \mathrm{C}$ and used within 10 days.

A pool of sera with high titres was used for a standard curve on each plate. It was diluted between $1 / 1500$ and $1 / 50000$ in phosphate buffered saline, $1 \%$ BSA. Test serum was diluted $1 / 1000$, or $1 / 10000$ in the same diluent. Each sample and standard was incubated in triplicate for 75 minutes at room temperature followed by washing three times with phosphate buffered saline for five minutes. Goat antihuman IgG ( $\gamma$-chain specific) congugated to horseradish peroxidase (Zymed Laboratories San Francisco, United States of America) was diluted 1/2000 in phosphate buffered saline, $1 \% \mathrm{BSA}$ and $100 \mu \mathrm{l}$ added to each well and left for two hours at room temperature. The wells were washed three times with phosphate buffered saline for five minutes. Then $100 \mu \mathrm{l}$ of substrate solution containing $5 \mathrm{mg}$ orthophenyldiamine and $20 \mu \mathrm{l}$ of $12 \% \mathrm{H}_{2} \mathrm{O}_{2}$ in $10 \mathrm{ml}$ citrate phosphate buffer $(2.43 \mathrm{ml}$ citric acid, $0.1 \mathrm{M}, 2.57 \mathrm{ml}$ sodium

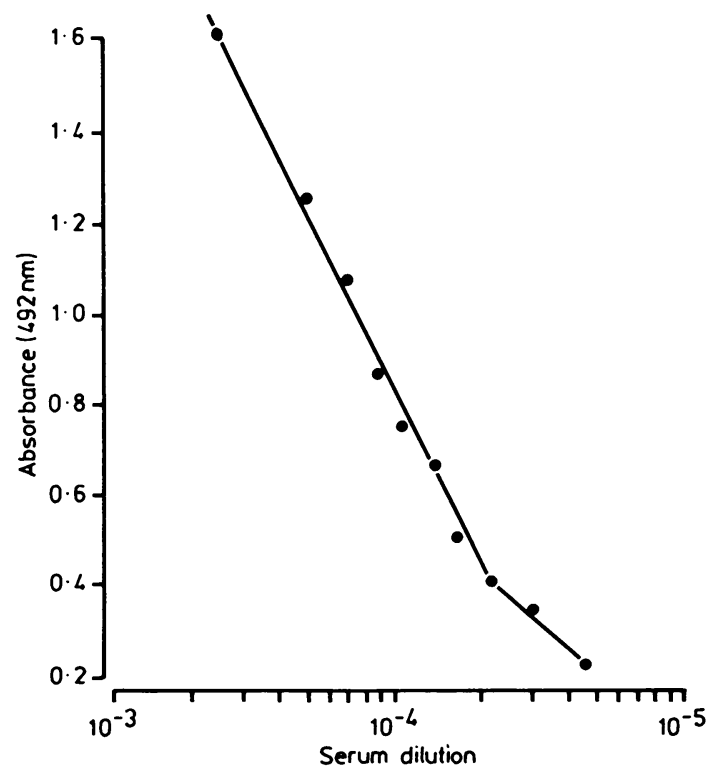

Enzyme linked immunosorbent assay standard curve for serum IgG antibodies to $P$ aeruginosa serotype 11. 
Table 1 Absorbance at 492 nm produced by IgG antibodies from serum of patients with cystic fibrosis diluted 1/1000 against eight speciestof Gram negative bacteria in ELISA

\begin{tabular}{|c|c|c|c|c|c|c|c|c|c|c|}
\hline \multirow[t]{2}{*}{ Case No } & \multicolumn{9}{|l|}{ Species } & $\because$ \\
\hline & $\begin{array}{l}\text { Proteus } \\
\text { mirabilis }\end{array}$ & $\begin{array}{l}\text { Seratia } \\
\text { marcescens }\end{array}$ & $\begin{array}{l}\text { Escherichia } \\
\text { coli }\end{array}$ & $\begin{array}{l}\text { Klebsiella } \\
\text { pneumoniae }\end{array}$ & $\begin{array}{l}\text { Citrobacter } \\
\text { amolenitus }\end{array}$ & $\begin{array}{l}\text { Citrobacter } \\
\text { diversus }\end{array}$ & $\begin{array}{l}\text { Enterobacter } \\
\text { cloacae }\end{array}$ & $\begin{array}{l}\text { Pseudomonas } \\
\text { aeruginosa } \\
\text { serotype } 11\end{array}$ & $\begin{array}{l}\text { Pseudomonas } \\
\text { aeruginosa } \\
\text { serotype } 6\end{array}$ & $\begin{array}{l}\overline{\vec{C}} \\
\stackrel{\square}{\check{C}}\end{array}$ \\
\hline 1 & $0.053^{*}$ & 0.051 & $0.040^{*}$ & 0.051 & 0.024 & 0.015 & 0.062 & 0.092 & 0.040 & $\overline{\overline{s 0}}$ \\
\hline 2 & 0.006 & 0.025 & 0.015 & $0.071^{*}$ & 0 & 0 & 0 & 0.042 & 0.079 & $\stackrel{\omega}{D}$ \\
\hline 3 & 0.018 & $0.018^{*}$ & 0.082 & 0.051 & 0.009 & 0.005 & 0.007 & 0.060 & 0.104 & $\overrightarrow{\mathbb{D}}$ \\
\hline 4 & 0.008 & 0.008 & 0.013 & 0.005 & 0 & 0 & 0 & $0.241^{*}$ & $0 \cdot 264^{*}$ & 으 \\
\hline 5 & $0.008^{*}$ & 0.013 & 0.016 & 0.012 & 0 & 0 & $0^{*}$ & $0.626^{*}$ & $0.398^{*}$ & ర్ల \\
\hline 6 & 0 & 0 & 0 & 0 & 0 & 0 & 0 & $10 \cdot 07^{+}$ & $13 \cdot 73_{ \pm}^{+}$ & $\rightarrow$ \\
\hline 7 & 0 & 0 & 0 & 0 & 0 & 0 & 0 & $10 \cdot 13_{t}^{t}$ & $2 \cdot 56_{ \pm}^{+}$ & $\overrightarrow{0}$ \\
\hline 8 & 0 & 0 & 0 & 0 & 0 & 0 & 0 & $9 \cdot 38_{+}^{+}$ & $4 \cdot 48+$ & \\
\hline
\end{tabular}

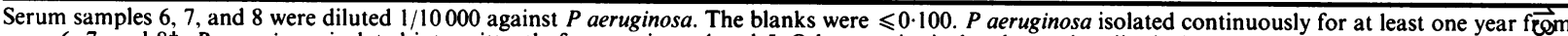
cases 6,7 , and $8+. P$ aeruginosa isolated intermittently from patients 4 and 5 . Other species isolated occasionally during the previous year.*

phosphate, $0.2 \mathrm{M}$ and $5.0 \mathrm{ml}$ distilled water) was added. The reaction was allowed to proceed for two minutes in daylight and then was stopped by adding $100 \mu \mathrm{l} 4 \mathrm{M} \mathrm{H}_{2} \mathrm{SO}_{4}$. Absorption at $492 \mathrm{~nm}$ was measured using a Titerteck plate reader. Absorbance was $\leqslant 0 \cdot 10$ in wells containing no adsorbed antigen, or no test serum, or no labelled antibody. The blank was subtracted from the test absorbance. To standardise the results and eliminate day to day variation this value was converted to a dilution by reference to the standard curve. The figure shows a typical standard curve. The reciprocal of the dilution used for the patient's serum was divided by the reciprocal of the dilution obtained from the standard curve, multiplied by 1000 , and expressed as a titre. Serum from each patient was tested against all antigens on the same day. The titre of one sample measured on six occasions gave a mean (SE) of 5558 (463).

\section{Results}

All Paeruginosa isolates from patients with cystic fibrosis were serotyped for six months. After this preliminary work it was decided to test serum against strains with serotypes $1,3,6,9,10,11$, and a nontypable strain. These represented $85 \%$ of isolates obtained from our patients during the previous six months.

Serum from eight patients with cystic fibrosis was tested by ELISA against two strains of $P$ aeruginosa and eight other species of Gram negative bacteria. The absorbance produced by serum from patients $1-5$ against non-pseudomonal strains was less than 0.090 (table 1). In contrast, the absorbance produced against $P$ aeruginosa was considerably higher in the two patients (cases 4 and 5) from whom it had been isolated intermittently. Serum from patients that grew $P$ aeruginosa continuously (cases 6,7 , and 8 ) produced no detectable reaction against nonpseudomonal bacteria but an extremely high reaction against $P$ aeruginosa. These results indicate that the contribution of antibodies to other species towards the reaction against $P$ aeruginosa was negligible.

Sera from 17 paediatric patients without cystic fibrosis and no known Paeruginosa infection were $\vec{N}$ tested for IgG antibodies by ELISA. Table 2 shows $\rightarrow$ the sum titre to seven serotypes and the highest titre 의 against an individual serotype. The highest titre against a single strain was 35 . The sum titre to all seven serotypes ranged from 140 to 250 , with a mean of 200.

The titre of serum from five patients with cystic fibrosis with no history of Paeruginosa infection is also shown (table 2). These titres were low. There was no correlation between titre and either age or sex.

Table 3 shows the titre of serum from seve patients from whom Paeruginosa had been isolated intermittently. There was a wide spread of titres within this group of patients. Paeruginosa was isolated less than four times from cases 1-4. Titres greater than control values were present against one or two different strains in these patients. Paeruginosa had been isolated intermittently for one to two years from cases 5 and 6 and continuously for four months from case 7 . In these patients titres against all serotypes were greater then those of control values. In two

Table 2 ELISA titre produced by serum IgG antibodies to $P$ aeruginosa in patients with and without cystic fibrosis with no $P$ aeruginosa infection

\begin{tabular}{lcc}
\hline & $\begin{array}{c}\text { Without cystic } \\
\text { fibrosis } \\
(n=17)\end{array}$ & $\begin{array}{l}\text { With cystic } \\
\text { fibrosis } \\
(n=5)\end{array}$ \\
\hline Titre to seven serotypes & $140-250$ & $140-180$ \\
Range mean (SD) & $200(7)$ & $150(7)$ \\
Highest individual titre & $20-38$ & $20-31$ \\
Range mean (SE) & $29(0 \cdot 9)$ & $25(2 \cdot 5)$ \\
Age range & $5 \mathrm{~m}-15 \mathrm{y}$ & $1-15$ \\
Mean years (SE) & $9 \cdot 54(1 \cdot 42)$ & $8 \cdot 4(2 \cdot 11)$ \\
The strains used were serotype $1,3,6,9,10,11$, and a non-typable \\
strain.
\end{tabular}


Table 3 Serum IgG ELISA titre against $P$ aeruginosa in patients with cystic fibrosis patients who grew $P$ aeruginosa intermittently

\begin{tabular}{|c|c|c|c|c|c|c|c|}
\hline \multirow[t]{2}{*}{$P$ aeruginosa serotype } & \multicolumn{7}{|c|}{ Case No } \\
\hline & $\bar{l}$ & 2 & 3 & 4 & 5 & 6 & 7 \\
\hline $\begin{array}{l}1 \\
3 \\
6 \\
9 \\
10 \\
11 \\
\text { Non-typable } \\
\text { Sum } \\
\text { Sputum serotype }\end{array}$ & $\begin{array}{l}71 \\
71\end{array}$ & $\begin{array}{r}82 \\
167\end{array}$ & 168 & $\begin{array}{l}140 \\
140\end{array}$ & $\begin{array}{c}115 \\
69 \\
154 \\
75 \\
76 \\
425 \\
106 \\
1014 \\
1,10\end{array}$ & $\begin{array}{r}45 \\
200 \\
170 \\
145 \\
74 \\
600 \\
100 \\
1334 \\
6\end{array}$ & $\begin{array}{r}570 \\
650 \\
295 \\
300 \\
80 \\
250 \\
590 \\
2735 \\
\text { NT, } 1\end{array}$ \\
\hline
\end{tabular}

Serotypes to the international antigenic typing scheme. ${ }^{4}$

Table 4 Serum IgG ELISA titre against $P$ aeruginosa in patients with cystic fibrosis continuously infected with $P$ aeruginosa

\begin{tabular}{|c|c|c|c|c|}
\hline \multirow[t]{2}{*}{$P$ aeruginosa serotype } & \multicolumn{4}{|c|}{ Case No } \\
\hline & $l$ & 2 & 3 & 4 \\
\hline 1 & 145 & 515 & 210 & 720 \\
\hline 3 & 100 & 310 & 250 & 300 \\
\hline 6 & 160 & 870 & 1690 & 1030 \\
\hline 9 & 155 & 600 & 1630 & 810 \\
\hline 10 & 325 & 1750 & 4170 & 2400 \\
\hline 11 & 205 & 1100 & 2780 & 1750 \\
\hline Not typable & 200 & 860 & 1560 & 1640 \\
\hline Sum & 1290 & 6005 & 12290 & 8650 \\
\hline Sputum serotype & 10 & 10,11 & 10.11 & NT, 1,9 \\
\hline
\end{tabular}

Serotypes according to the international typing scheme. ${ }^{4}$

patients (cases 5 and 7) the serotype producing the highest titre was the same as the serotype isolated from sputum but this was not the case for case 6 .

Table 4 shows titres in four patients that grew $P$ aeruginosa continuously for over a year. There was a wide spread of titres to individual strains. Titres were appreciably higher than those in the other groups of patients. In three of these four patients the serotype(s) producing the highest titre were those isolated from sputum.

\section{Discussion}

The purpose of this work was to develop a test, suitable for routine use, to measure the humoral immune response associated with Paeruginosa infection in patients with cystic fibrosis. Of the several antigens tested, cells treated with glutaraldehyde gave the most reproducible results and the widest spread of titres between controls and patients with cystic fibrosis chronically infected with Paeruginosa. Glutaraldehyde is a polyaldehyde that cross links the amino groups present in proteins exposed at the bacterial surface. ${ }^{5}$ These amino groups are also present in the lipopolysaccharide (in alanine and amino sugars) of the serotypes used here. ${ }^{6}$ The cells were bound to the ELISA plates by methylglyoxal. Although the mechanism of action of methylglyoxal is not known, it probably behaves like other polyaldehydes-cross linking between amino groups or by electrostatic action with polystyrene. ${ }^{5}$

In preliminary studies two or more strains of the same O-serotype were used. Titres against each strain were within $5 \%$ on repeated tests with the same serum. Different strains of the same serotype, however, did not always give the same titre with the same serum $(2-15 \%)$. This may have been due to a different amount or conformation of the O-serotype antigen, presence of additional weakly reacting O-serotypes, or, varying amount, exposure, or conformation of either the outer membrane proteins or other protein antigens such as flagellar antigen. ${ }^{7}$ Although the outer membrane proteins are highly conserved in $P$ aeruginosa, ${ }^{89}$ quantitative studies using monoclonal antibodies have shown that the amount of antibody binding to protein I was similar in 17 strains, while the amount of antibody binding to protein $\mathrm{H} 2$ was different. ${ }^{9}$ Because the purpose of this work was the early detection of humoral antibodies, the strain producing the highest titre was used in the routine test.

Antibodies directed against other Gram negative bacteria did not seem to make a quantitatively important contribution to the titre against $P$ aeruginosa in this assay. In a radioimmunoassay using rabbit antipseudomonal serum to detect bacte- 
rial cells in urine Kohler et al reported that cross reaction with other Gram negative bacteria was low. ${ }^{10}$

The results presented here show that antibodies reacting with Paeruginosa were present at very low titres both in patients with cystic fibrosis and in the control group with no known Paeruginosa infection. Hoiby, using counterimmunoelectrophoresis, showed that the prevalence of precipitating antibodies against sonicated $P$ aeruginosa increased gradually with age in a normal population. These antibodies, however, were present only at low titres and were directed against two antigens that cross reacted with antigens from other bacterial species. ${ }^{11}{ }^{12}$ In a survey of 100 adults of unspecified age, using ELISA, serum antibodies against $P$ aeruginosa surface antigens were also present at low titres. ${ }^{13} \mathrm{We}$ found that patients who grew $P$ aeruginosa continuously had very high antipseudomonal IgG antibodies, while patients who grew that organism intermittently had titres that were lower but still greater than those of the controls. There was a wide spread of titres in both groups of patients (tables 3 and 4 ).

The serotype that produced the highest titre was not always the same serotype as the sputum isolate. There are several possible reasons for this: a strain may be present in the lungs but not be detectable in the sputum; organisms present in numbers less than $10^{4} \mathrm{ml}$ are unlikely to be detected by the protocol used in our laboratory. Furthermore, treatment with nebulised antibiotics may kill organisms in sputum but not all those present in the lungs. The number of different strains isolated from a chronically infected patient was often at least five and commonly more than 10 on daily examination over a week or two, but each strain was not isolated from every sputum sample. This may have been due to sampling of sputum from different regions of the lungs, which contain different strains. Sputum from most patients was obtained at intervals of weeks or months rather than days and so may not have given a complete picture.

Another possible reason for the discrepancy between serotype of sputum isolates and serum antibody is that serum IgG formation and removal is not instantaneous. Therefore an organism may be present in sputum for a few weeks before serum IgG antibodies can be detected. Similarly, a decline in antibody titre is likely to occur some weeks after complete removal of the antigen.

Finally, a high titre may be caused by antibodies reacting with cell surface components other than the $\mathrm{O}$-serogroup. The non-typable strain used in this assay often produced a high titre. This may be caused by antibodies directed against the core region of lipopolysaccharide, the cell membrane proteins, or other cell surface antigens. Several workers have reported antibodies to surface components other than the lipo- 0 polysaccharide side chain. Hancock et al reported $\stackrel{0}{*}$ antibodies specific to the core region of lipo- 으 polysaccharide in $74 \%$ of chronically infected patients with cystic fibrosis, ${ }^{14}$ while absorption of $\stackrel{\vec{\rho}}{9}$ rabbit immune serum with the core region of lipopolysaccharide removed only $50 \%$ of antibodies. ${ }^{15}$ Antibodies to outer membrane proteins have been $\frac{\bar{\omega}}{\overrightarrow{0}}$ shown in experimentally infected mice ${ }^{1617}$ and $\stackrel{\mathbb{Q}}{\propto}$ patients with cystic fibrosis chronically infected with Paeruginosa. ${ }^{11} 18$ Vaccination of mice with purified 2 protein $\mathrm{F}$ (Porin) was shown to have a protective effect against infection in mice. ${ }^{19}$

In conclusion, the assay reported here is both a sensitive and specific monitor of IgG antibodies directed 용 against $P$ aeruginosa cell surface components and is $\omega$ suitable for routine use. Antibody titres in control patients were low. In patients with cystic fibrosis antibody titre increased with length of Paeruginosa $\overrightarrow{\vec{N}}$ infection. Work is currently in progress to assess the $\stackrel{N}{\perp}$ value of this test for monitoring the progress of $P$ aeruginosa infection in a larger number of patients and in differentiating between early colonisation and infection.

This work was supported by the Cystic Fibrosis Research Trust, United Kingdom (grant No 244).

\section{References}

1 Mearns MB. Natural history of pulmonary infection in cystic fibrosis. In: Sturgess M, ed. Proceedings of the eighth international cystic fibrosis congress. Toronto: Canadian Cystic Fibrosis Foundation, 1980:323-34.

2 Hoiby N. Pseudomonas aeruginosa infection in cystic fibrosis. Acta Pathol Microbiol Scand (Sect C) 1977;262 (Suppl):1-95.

3 Gibson LE, Cooke RE. A test for concentration of electrolytes in sweat in CF of the pancreas utilizing pilocarpiniontophoresis. Pediatrics 1959;23:545-9.

4 Liu PV, Matsumoto H, Kusama H, Bergan T. Survey of heatstable, major somatic antigens of Pseudomonas aeruginosa. Int J System Bacteriol 1983;33:256-64.

5 Peters K, Richards FM. Chemical cross linking reagants and problems in studies of membrane structure. Analytical Biochemistry 1978;46:523-51.

6 Lanyi B, Bergen T. Serological characterisation of Pseudomonas aeruginosa. Methods in Enzymology 1978;10:93-168.

7 Stanislavsky ES, Dmitriev BA, Lanyi B, Joo I. Antigens of $\frac{D}{2}$ Pseudomonas aeruginosa and their use in immunoprophylaxis and immunotherapy. Int J System Bacteriol 1985;33:256-64. N

8 Hancock REW, Mouat ECA, Speert DP. Quantitation and $\sigma$ identification of antibodies to outer membrane proteins of $\mathrm{N}$ Pseudomonas aeruginosa in sera of patients with cystic $\mathrm{N}$ fibrosis. J Infect Dis 1984;149:220-6.

9 Hancock REW, Wieczorek AW, Mutharia LM, Poole K. Mono- 무 clonal antibodies against Pseudomonas aeruginosa outer membrane antigens: isolation and characterisation. Infect Immun 1982;37:166-71.

10 Kohler RB, Wheat J, White A. Rapid diagnosis of Pseudomonas aeruginosa urinary tract infection by radioimmunoassay. $J$ Clin Microbiol 1979;9:253-8. 
11 Hoiby N. Normally occurring precipitating antibodies against Pseudomonas aeruginosa. Prevalence, specificities and titres. Scand J Immunol 1975;2:(suppl)197-202.

12 Hoiby N. Antibodies against Pseudomonas aeruginosa in serum from normal persons and patients colonised with mucoid or non-mucoid Pseudomonas aeruginosa: results obtained by crossed immunoelectrophoresis. Acta Pathol Microbiol Scand (Sect C) 1977;85:142-8.

13 Cost KM, West CS, Brinson D, Polk HC. Measurement of human antibody activity against Escherichia coli and Pseudomonas aeruginosa using formalin treated whole organisms in an ELISA technique. J Immunoassay 1985;6:23-43.

14 Hancock REW, Mouat ECA, Speert DP. Quantitation and identification of antibodies to outer-membrane proteins of Pseudomonas aeruginosa in sera of patients with cystic fibrosis. J Infect Dis 1984;149:220-6.

15 Borowski RS, Stock LM, Schiller NL. Development of an enzyme-linked immunosorbent assay for studying Pseudomonas aeruginosa cell surface antigens. J Clin Microbiol 1984;19:736-41.
16 Hedstrom RC, Pavlovkis OR, Galloway DR. Antibody response of infected mice to outer membrane proteins of Pseudomonas aeruginosa. Infect Immun 1984;43:49-54.

17 Jones Danneman P, Michael JG. Reaginic antibody protein antigens of Escherichia coli and Pseudomonas aeruginosa by mice. Infect Immun 1976;14:694-702.

18 Lam JS, Mutharia LM, Hancock REW, et al. Immunogenicity of Pseudomonas aeruginosa outer membrane antigens examined by crossed immunoelectrophoresis. Infect Immun 1983;42: 88-98.

19 Gilleland Jr HE, Parker MG, Mathews JM, Berg RD. Use of a purified outer membrane protein $F$ (Porin) preparation of Pseudomonas aeruginosa as a protective vaccine in mice. Infect Immun 1984;44:49-54.

Requests for reprints to: Dr MM Brett, Department of Medicine, St. James's University Hospital, Beckett St, Leeds LS9 7TF, England. 